University of Nebraska - Lincoln

DigitalCommons@University of Nebraska - Lincoln

Agronomy \& Horticulture -- Faculty Publications

Agronomy and Horticulture Department

2006

Resistance gene analog polymorphism (RGAP) markers colocalize with disease resistance genes and QTL in common bean

\author{
Nedim Mutlu \\ University of Nebraska-Lincoln, nmutlu2@unl.edu \\ Phillip Miklas \\ USDA, ARS \\ Dermot Coyne \\ University of Nebraska-Lincoln
}

Follow this and additional works at: https://digitalcommons.unl.edu/agronomyfacpub

Part of the Plant Sciences Commons

Mutlu, Nedim; Miklas, Phillip; and Coyne, Dermot, "Resistance gene analog polymorphism (RGAP) markers co-localize with disease resistance genes and QTL in common bean" (2006). Agronomy \& Horticulture -Faculty Publications. 143.

https://digitalcommons.unl.edu/agronomyfacpub/143

This Article is brought to you for free and open access by the Agronomy and Horticulture Department at DigitalCommons@University of Nebraska - Lincoln. It has been accepted for inclusion in Agronomy \& Horticulture -Faculty Publications by an authorized administrator of DigitalCommons@University of Nebraska - Lincoln. 


\title{
Resistance gene analog polymorphism (RGAP) markers co-localize with disease resistance genes and QTL in common bean
}

\author{
Nedim Mutlu ${ }^{1,2, *}$, Phillip N. Miklas ${ }^{3}$ and Dermot P. Coyne ${ }^{2}$ \\ ${ }^{1}$ Present address: Bati Akdeniz Agricultural Research Institute, P.O. Box 35, 07100 Antalya, Turkey; \\ ${ }^{2}$ Department of Agronomy and Horticulture, University of Nebraska, Lincoln, NE 68683, USA; ${ }^{3} U S D A-$ \\ ARS, Vegetable and Forage Crop Research Unit, 24106 North Bunn Road, Prosser, WA 99350, USA; \\ *Author for correspondence (e-mails: nmutlu2@unlnotes.unl.edu; severmutlu@hotmail.com; phone: +90- \\ 2423216796; fax: +90-2423211512)
}

Received 12 December 2004; accepted in revised form 21 October 2005

Key words: Core map, Disease resistance, Gene clusters, Phaseolus vulgaris, R gene

\begin{abstract}
Resistance (R) genes containing nucleotide-binding site (NBS)-leucine rich repeats (LRR) are the most prevalent types of $\mathrm{R}$ gene in plants. The objective of this study was to develop PCR-based R-gene analog polymorphism (RGAP) markers for common bean (Phaseolus vulgaris L). Twenty degenerate primers were designed from the conserved kinase-1a (GVGKTT) and hydrophobic domains (GLPLAL) of known NBSLRR type R-genes and from EST databases. Sixty-six of the 100 primer combinations tested yielded polymorphism. Thirty-two RGAP markers were mapped in the BAT 93/Jalo EEP558 core mapping population for common bean. The markers mapped to 10 of 11 linkage groups with a strong tendency for clustering. In addition, the RGAP markers co-located, on six linkage groups, with 15 resistance gene analogs (RGAs) that were previously mapped in other populations of common bean. The distance between the priming sites in NBS-LRR type R-genes is around $500 \mathrm{bp}$. Of the 32 RGAP markers, 19 had sizes larger and 13 less than 500 bp. RGAP markers mapped close to known R-genes on B11, and to QTLs for resistance on B1, B2, B6, B7, B8, B10, and B11. RGAP appears to provide a useful marker technique for tagging and mapping R-genes in segregating common bean populations, discovery of candidate genes underlying resistance QTL, and future cloning of R-genes in common bean.
\end{abstract}

Abbreviations: HD - Hydrophobic domain; K - Kinase; LG - Linkage group; QTL - Quantitative trait locus/loci; RGAP - Resistance gene analog polymorphism

\section{Introduction}

Plant disease resistance often results from the presence of a specific resistance $(\mathrm{R})$ gene in the plant and a corresponding avirulence (avr) gene in the pathogen (Flor 1956). These gene-for-gene relationships explain quantitative disease resistance in most of plant pathogens. Several R-genes corresponding to race-specific interactions have been isolated by map-based cloning and transposon tagging (reviewed by Baker et al. 1997). All known R-genes can be grouped into a few classes 
based on their sequence structure and functional domains/motifs. Most of these R-genes belong to the nucleotide-binding site (NBS)-leucine rich repeat (LRR) type (Martin 1999). R-genes of this class share conserved domains and structural similarities even though they are from diverse taxonomic groups (monocots and dicots), and confer resistance to viral, fungal or bacterial pathogens. Specific domains are thought to participate in signal transduction and protein-protein interactions (Staskawicz et al. 1995; Bent 1996). The NBS-containing protein is thought to activate a kinase, or act as a G-protein, each being part of a signal transduction pathway (Bent 1996).

Although the overall sequence homology among members of the NBS-LRR class is low and insufficient to be detected by cross hybridization, short stretches of peptide sequences are well-conserved (Staskawicz et al. 1995; Hammond-Kosack and Jones 1997). The conserved motifs at the NBS (GVGKTT) and hydrophobic sites (GLPLAL) have enabled a novel polymerase chain reaction (PCR)-based approach that uses degenerate primers to amplify RGAs from many plant species. This approach was extensively used to clone genomic copies after PCR amplification of NBS-LRR sequences, and then sequence and map via restriction fragment length polymorphism (RFLP) in many plant species (Kanazin et al. 1996; Leister et al. 1996, 1998; Rivkin et al. 1999; Deng et al. 2000).

Genetic analyses have associated a number of RGAs to known R-gene loci that confer resistance to viruses, bacteria, fungi or nematodes in a number of crop species (Kanazin et al. 1996; Leister et al. 1996; Yu et al. 1996; Aarts et al. 1998; Shen et al. 1998; Speulman et al. 1998; Spielmeyer et al. 2000). For instance, map positions of RGAs in Arabidopsis correspond to 21 different disease resistance loci (Speulman et al. 1998). Similarly, Aarts et al. (1998) observed that most of the cloned RGAs in Arabidopsis were genetically linked with disease resistance loci. Two RGAs were mapped to known disease resistance clusters in lettuce (Shen et al. 1998). QTLs for resistance and RGAs were also shown to be linked in pepper (Capsicum annum L.) (Pflieger et al. 1999), soybean (Glycine max L.) (Kanazin et al. 1996), sunflower (Helianthus annuus L.) (Gentzbittel et al. 1998) and common bean (Geffroy et al. 1998, 2000; Creusot et al. 1999; Rivkin et al. 1999; Lopez et al. 2003). None of the
RGA markers co-segregated with disease resistance loci in cowpea (Vigna unguiculata L.), a closely related legume to common bean (Ouedraogo et al. 2002), however, this could be due to the lack of systematic mapping of disease R-genes in this species. Most of the NBS-LRR containing sequences were observed to be clustered in various plant species (Leister et al. 1996; Yu et al. 1996; Collins et al. 1998). Similarly, functional R-genes are also clustered. Genes for resistance to different pathogens formed clusters at three genomic regions in potato (Gebhardt and Valkonen 2001). $D m$ genes of lettuce (Meyers et al. 1998), the $C f$ genes of tomato (Jones et al. 1994; Dixon et al. 1998), and Mla genes of barley were all present in clusters. These clusters overlap with the mapped NBS-LRR sequences.

Common bean is an economically important crop that is grown throughout the world. Pests and diseases constrain bean production, affecting yield and seed quality. Disease resistance genes are known in common bean and have been placed on the core map (Kelly et al. 2003). Dominantly inherited rust (Uromyces appendiculatus) and anthracnose (Colletotrichum lindemuthianum) resistance genes and resistance gene clusters harboring QTL for resistance are likely targets in this study.

The objective of this study was to develop PCRbased resistance gene analog polymorphism (RGAP) markers to provide a basis for mapping candidate genes and QTL for disease resistance in common bean. A PCR approach (sans cloning and sequencing) with degenerate primers based on two conserved motifs of NBS-LRR type plant R-genes was employed to develop RGAP markers. The mapping and co-localization of 32 RGAPs in the common bean core map is described.

\section{Materials and methods}

\section{Plant materials and primers}

Degenerate primers were designed from highly conserved motifs, kinase-1a (K) and hydrophobic domain (HD) of NBS-LRR type resistance genes. NBS-LRR sequences were obtained from known $\mathrm{R}$-genes and EST databases of dicots in order to target the gene family. First, $\mathrm{K}$ and HD peptide sequences were aligned and the most conserved 
domain sequences were determined. Second, codon preferences from the EST sequences were identified for the domains having identical peptide sequences. Six different peptide sequences corresponding to the $\mathrm{K}$ motif and seven different peptide sequences corresponding to HD motif were used to design $10 \mathrm{~K}$ and $10 \mathrm{HD}$ degenerate primers, respectively (Table 1 ). The degree of degeneracy ranged from ' 0 ' (HD01 and HD02) to '432' (K07 and K08) (Table 1). In the PCR reaction, K primers acted as forward and HD primers as reverse primers. One hundred combinations of a ' $\mathrm{K}$ ' and an 'HD' primer $(10 \mathrm{~K} \times 10 \mathrm{HD})$ were used for the initial survey for polymorphisms between BAT 93 and Jalo EEP558, parental lines of a 'core' common bean mapping population consisting of 72 recombinant inbred lines (RILs) (Freyre et al. 1998). Polymorphisms detected between the parents were assayed across the RILs. The RIL lines were kindly provided by Dr. P. Gepts, University of California, Davis, CA. The two parents of the population are evolutionarily diverse, BAT 93 is from the Middle American gene pool and Jalo EEP558 is from the Andean gene pool. These two parental lines possess contrasting phenotypic disease responses to anthracnose, bean common mosaic virus, and common bacterial blight (Xanthomonas axonopodis pv. phaseoli). In addition, many other disease resistance genes and QTL have been mapped indirectly in the BAT 93/ Jalo EEP558 core population as a result of map integration from other studies (Kelly et al. 2003; unpublished data). BAT 93 was developed at the Centro Internacional de Agricultura Tropical (CIAT, Cali, Colombia) as a breeding line and was derived from a double cross involving four Middle American genotypes (Veranic 2, PI 207262, Jamapa, and Great Northern Tara). Jalo EEP558 is a selection from the Andean landrace Jalo obtained at the Estação Experimental de Pato de Minas (Minas Gerais, Brazil).

In Figure 1, the primer combinations were numbered as follows; $\mathrm{K} 01$ primer in combination with HD01 to HD10 primers was numbered as $\mathrm{K} 1 \mathrm{H} 1$ to K1H10. Similar combinations of K02 with the $\mathrm{HD}$ primers were numbered as $\mathrm{K} 2 \mathrm{H} 1$ to $\mathrm{K} 2 \mathrm{H} 10$ and so on to K10H10. The scored RGAP markers with their molecular size (base pair) and originating parent BAT 93 (a) or Jalo EEP558 (b) are denoted following the marker name. The marker $\mathrm{K} 5 \mathrm{H} 8 \mathrm{~b} .490$, for instance, is amplified with $\mathrm{K} 05$ and HD08 primer combinations and is a $490 \mathrm{bp}$ molecular size fragment that originates from Jalo EEP558.

Table 1. The sequences (both DNA and peptide), melting temperatures $\left(T_{\mathrm{m}}\right)$, and degree of degeneracy of kinase-1a (K) (forward) and hydrophobic domain (HD) (reverse) degenerate primers.

\begin{tabular}{|c|c|c|c|c|}
\hline Primer & Sequence (DNA) & $T_{\mathrm{m}}\left({ }^{\circ} \mathrm{C}\right)$ & Degeneracy $^{\mathrm{a}}$ & Amino acid \\
\hline K01 & $5^{\prime}$ GGS GGG GTG GGG AAG ACS AC $3^{\prime}$ & 65.6 & 4 & GGVGKTT \\
\hline K02 & $5^{\prime}$ GGW GGG GTT GGG AAG ACW AC $3^{\prime}$ & 58.3 & 4 & GGVGKTT \\
\hline K03 & 5'GGS GGS GTG GGT AAR ACD AC 3' & 60.9 & 24 & GGVGKTT \\
\hline K04 & 5'GGT GGC GTG GGC AAG ACD AC 3' & 62.8 & 3 & GGVGKTT \\
\hline K05 & 5'GGG GGS ATG GGY AAR ACD AC $3^{\prime}$ & 59.9 & 24 & GGMGKTT \\
\hline K06 & 5'GGH GGG ATG GGG AAR ACD AC $3^{\prime}$ & 59.0 & 18 & GGMGKTT \\
\hline K07 & 5'GGV GGV YTN GGC AAR ACD AC 3' & 59.9 & 432 & GGLGKTT \\
\hline K08 & 5'GGV GGV TCN GGS AAR ACD AC $3^{\prime}$ & 60.5 & 432 & GGSGKTT \\
\hline K09 & $5^{\prime}$ GGV GGV GTN GGS AAR AGY AC $3^{\prime}$ & 60.9 & 216 & GGVGKST \\
\hline K10 & $5^{\prime}$ GGV GGV ATH GGS AAR ACD AC 3' & 58.0 & 324 & GGIGKTT \\
\hline HD01 & $5^{\prime}$ GAG GGC GAG GGG GAG GCC 3' & 65.7 & 0 & GLPLAL \\
\hline HD02 & 5'CCA ACG CCA ATG GAA GAC C $3^{\prime}$ & 57.3 & 0 & GLPLAL \\
\hline HD03 & 5'AAG NCT AAR GGG AGG GCC $3^{\prime}$ & 57.1 & 8 & GLPLAL \\
\hline HD04 & $5^{\prime}$ GAG CGC CAR CGG GAG GCC $3^{\prime}$ & 65.8 & 2 & GLPLAL \\
\hline HD05 & $5^{\prime}$ GAG VGC GAA GGG GAG GCC $3^{\prime}$ & 62.6 & 3 & GLPFAL \\
\hline HD06 & $5^{\prime}$ GAG VGC CAR CGG NGA GCC $3^{\prime}$ & 63.3 & 24 & GSPLAL \\
\hline HD07 & 5'GAG VGC CAR SGG RTG GCC $3^{\prime}$ & 63.4 & 24 & GHPLAL \\
\hline HD08 & 5'GAG VGC CAR SGG YTT GCC 3' & 61.6 & 24 & GKPLAL \\
\hline HD09 & 5'GAG VGC CAR SGG RTT GCC $3^{\prime}$ & 61.2 & 24 & GNPLAL \\
\hline HD10 & 5'HTA VGC CAR KGG RTT GCC $3^{\prime}$ & 56.6 & 72 & GLPLAI \\
\hline
\end{tabular}

${ }^{\mathrm{a}}$ Degree of degeneracy of primer sequences, with degenerate nucleic acid bases underlined: $\mathrm{R}=\mathrm{A}, \mathrm{G} ; \mathrm{Y}=\mathrm{C}, \mathrm{T} ; \mathrm{K}=\mathrm{G}, \mathrm{T} ; \mathrm{S}=\mathrm{C}, \mathrm{G}$; $\mathrm{W}=\mathrm{A}, \mathrm{T} ; \mathrm{H}=\mathrm{A}, \mathrm{C}, \mathrm{T} ; \mathrm{V}=\mathrm{A}, \mathrm{C}, \mathrm{G} ; \mathrm{D}=\mathrm{A}, \mathrm{G}, \mathrm{T} ; \mathrm{N}=\mathrm{A}, \mathrm{C}, \mathrm{G}, \mathrm{T}$. 


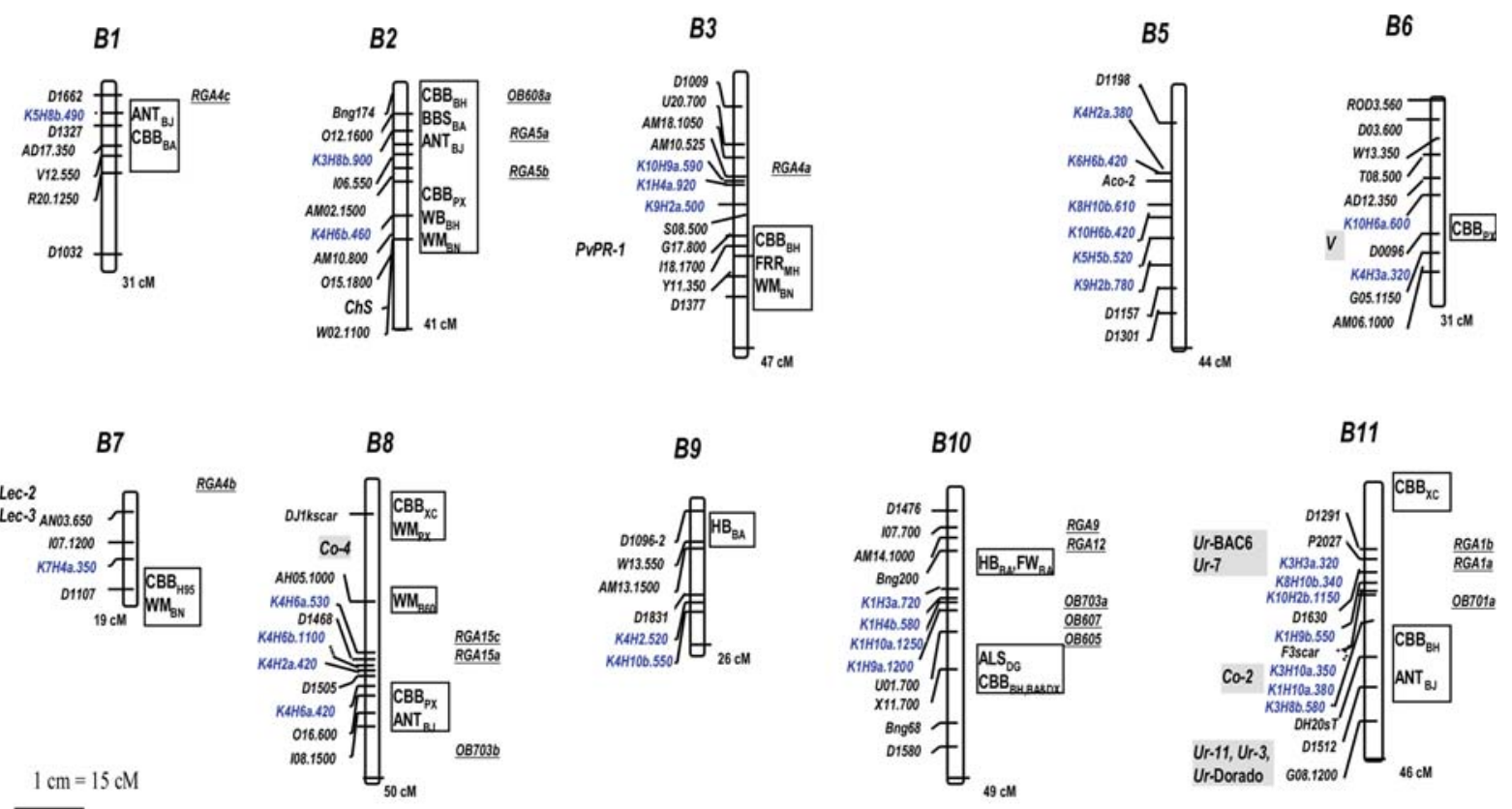

Figure 1. Partial linkage groups with 32 resistance gene analog polymorphism (RGAP) markers added to the integrated common bean core map BAT 93/Jalo EEP558 (Freyre et al. 1998). The RGAP markers (KH) with their molecular size (base pair) and originating parent BAT 93 (a) or Jalo EEP558 (b) denoted following the marker name and are listed on the left-hand side of the linkage group along with framework markers, pathogenesis genes (in bold far left), and resistance genes (shaded boxes, also far left) from the core map. Rectangles to the right of LGs represent approximate locations of quantitative trait loci (QTL) associated with resistance to different diseases: $\mathrm{ANT}=$ anthracnose; $\mathrm{BBS}=$ bacterial brown spot; $\mathrm{CBB}=$ common bacterial blight; $\mathrm{FRR}=$ Fusarium root rot; $\mathrm{FW}=$ Fusarium wilt $\mathrm{HB}=$ halo blight; $\mathrm{WB}=$ web blight; $\mathrm{WM}=$ white mold. Disease resistance QTL abbreviations are followed by the original mapping population in subscript (see Kelly et al. 2003; unpublished data). Approximate locations of previously mapped (Rivkin et al. 1999; Vallejos et al. 2001; Lopez et al. 2003) resistance gene analogs (RGA) are underlined far right of LGs. Partial map distances are given in cM. Location of most genes/QTL is approximate, as most were not directly mapped in the BAT 93/Jalo EEP558 population. For explanations on pathogenesis related genes see Kelly et al. (2003).

\section{PCR amplification conditions}

DNA amplification was performed in $10 \mu 1$ reaction mixtures containing $0.1 \mathrm{mM}$ dNTPs, 1 unit Taq polymerase, $2 \mu \mathrm{M}$ primers, and $1 \times$ reaction buffer $(2 \mathrm{mM} \mathrm{MgCl}, 50 \mathrm{mM}$ Tris, $20 \mathrm{mM} \mathrm{KCl}$, and $0.5 \mathrm{mg} / \mathrm{ml}$ BSA). The PCR reactions were performed in an air thermocycler (model Rapid Cycler; Idaho Technology, Idaho Falls, ID) in thin-walled glass capillary tubes.

PCR amplification conditions were as follows. After an initial denaturing step at $94{ }^{\circ} \mathrm{C}$ for $1 \mathrm{~min}$ $15 \mathrm{~s}$ products were amplified using 5 cycles of 94 ${ }^{\circ} \mathrm{C}$ for $10 \mathrm{~s}, 60{ }^{\circ} \mathrm{C}$ for $45 \mathrm{~s}$, and $72{ }^{\circ} \mathrm{C}$ for $1 \mathrm{~min}$ $10 \mathrm{~s}$, followed by 5 cycles of $91{ }^{\circ} \mathrm{C}$ for $10 \mathrm{~s}, 54{ }^{\circ} \mathrm{C}$ for $45 \mathrm{~s}, 72{ }^{\circ} \mathrm{C}$ for $1 \mathrm{~min} 10 \mathrm{~s}$, and 38 cycles of $91{ }^{\circ} \mathrm{C}$ for $10 \mathrm{~s}, 45^{\circ} \mathrm{C}$ for $20 \mathrm{~s}, 72{ }^{\circ} \mathrm{C}$ for $1 \mathrm{~min}$ 10 s. Amplification concluded with a final elongation step at $72{ }^{\circ} \mathrm{C}$ for 4 min 30 s. All PCR products were separated on a $1.2 \%$ agarose gel and visualized with ethidium bromide staining under ultraviolet light.

\section{Segregation and linkage analysis}

The RGAP markers that segregated in the RIL population were integrated with 120 framework marker data (http://agronomy.ucdavis.edu/gepts/ bjril7.htm) that span the BAT 93/Jalo EEP558 core linkage map (Freyre et al. 1998), using a Macintosh version of MAPMAKER 2.0 Lander et al. 1987). The RGAP markers re-grouped with the framework markers and added to the map using 'COMPARE' command (up to seven markers). However, when there were more than seven markers in a group, additional markers were added using the 'TRY' command. All RGAP 
markers were inserted that could be placed with a LOD difference greater than 2.0 between most likely and second most likely interval for that marker. The Kosambi (Kosambi 1944) unit was used to express map distances. Goodness-of-fit tests for 1:1 segregation ratio and independence tests were performed for the mapped RGAP markers using Microsoft Excel spreadsheet software.

\section{Results}

To identify the RGAP polymorphisms between the two parental lines of common bean, 100 primer combinations $(10 \mathrm{~K} \times 10 \mathrm{HD})(\mathrm{KH}$ primer combinations) were used for the polymorphism survey of the two parents of the mapping population. Each $\mathrm{KH}$ primer combination amplified an average of 2.7 bands with a range of $0-7$, but only 66 of the bands were polymorphic between BAT 93 and Jalo EEP558 common bean lines and subsequently mapped across the RILs (supplemental data). Of the 66 RGAP markers only 32 were selected for inclusion in the core map (Figure 1). The remain- ing 34 RGAPs were excluded because they clustered on the map with two or more RGAP markers. Thus, only one representative RGAP marker was selected from such clusters of RGAPs that mapped to the same locus and represented same-sized bands amplified from a given parent. Clusters of RGAPs were expected because primers similar in sequence with low degeneracy are likely to amplify identical products. For example, K2H6, K5H6, K6H6, K8H6, and K9H6 primer combinations all produced $420 \mathrm{bp}$ RGAP fragments amplified from the parent Jalo EEP558 that mapped to the exact same location on linkage group (LG) B5, but only the RGAP from K6H6 was placed on the map representing all five markers. However, marker and map data for all 66 polymorphisms is provided in the supplemental data because of potential use of the excluded markers in other segregating populations of common bean. Representative RGAPs generated with $\mathrm{KH}$ primer sets is presented in Figure 2.

The 32 selected RGAP mapped to 24 different loci distributed across all linkage groups except B4 (Figure 1). RGAP markers clustered on B3, B5, $\mathrm{B} 8, \mathrm{~B} 10$ and B11. Five of the markers showed
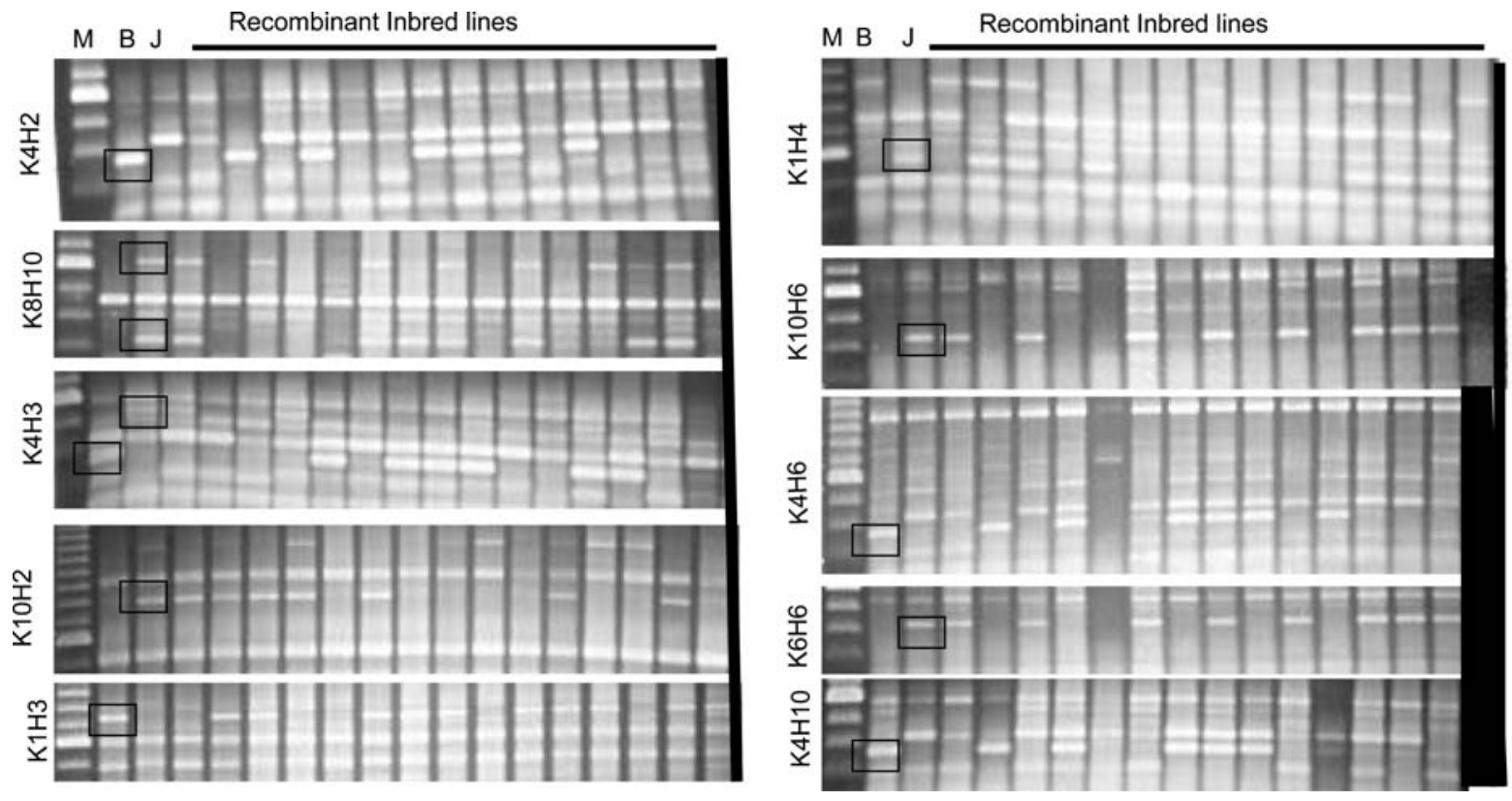

Figure 2. Representative PCR amplification profiles from 1.2\% agarose gels stained by ethidium bromide and visualized under UV light depicting RGAP markers in the parents BAT 93 (B), and Jalo EEP558 (J) and a small subset of recombinant inbred lines from the core map (BAT 93/Jalo EEP558) for different kinase (K) and hydrophobic domain (HD) primer combinations (see Table 1). $\mathrm{M}=100$ bp DNA size marker (Invitrogen). 
significant distortion $(p=0.05)$ from the expected 1:1 ratio, with four having an excess of the BAT 93 locus. The markers mapped close to R-genes on B11; and to QTL for resistance on B1, B2, B6, B7, $\mathrm{B} 8, \mathrm{~B} 10$, and $\mathrm{B} 11$. The RGAP markers $\mathrm{K} 3 \mathrm{H} 3 \mathrm{a}$, K8H10b，K10H2b，K1H9b，K3H10a，K1H10a, and $\mathrm{K} 3 \mathrm{H} 8 \mathrm{~b}$ on $\mathrm{B} 11$ were mapped in the vicinity of known R-genes, $U r-7$ and $U r$-BAC6 for resistance to bean rust and $\mathrm{Co}-2$ for resistance to bean anthracnose, and also QTL for resistance to anthracnose (ANT) and common bacterial blight (CBB). The other RGAPs were linked with QTL for resistance to ANT and $\mathrm{CBB}$ on B1; ANT, bacterial brown spot (BBS) caused by Pseudomonas syringae pv. syringae, web blight (WB) caused by Thanatephorus cucumeris, and white mold (WM) caused by Sclerotinia sclerotiorum on B2; $\mathrm{CBB}$ on $\mathrm{B} 6$ (CBB); $\mathrm{CBB}$ and $\mathrm{WM}$ on B7; ANT and $\mathrm{CBB}$ on B8; and angular leaf spot (ALS) caused by Phaeoisariopsis griseola, $\mathrm{CBB}$, halo bacterial blight (HB) caused by Pseudomonas syringae pv. phaseolicola, and Fusarium wilt caused Fusarium oxysporum f.sp. phaseoli on B10. The six RGAP markers on B5 were not associated with any known resistance genes/QTL in common bean.

The approximate locations of RGAs reported by Rivkin et al. (1999) and Lopez et al. (2003) in the core map depicted in Figure 1 were obtained by utilizing common markers from the maps of Freyre et al. (1998), Vallejos et al. (2001), and Kelly et al. (2003). Six RGAs from Rivkin et al. (1999) labeled 'OB' were located on B2, B8, B10, and B11 (Vallejos et al. 2001), and 11 RGAs from Lopez et al. (2003) labeled 'RGA' were placed on B1, B2, B3, B7, B8, B10, and B11. The RGAP markers co-localized with one or more of these RGAs on B1, B2, B3, B8, B10, and B11 (Figure 1).

The size of the intervening region in any NBSLRR type plant $\mathrm{R}$-gene between priming sites ( $\mathrm{K}$ and HD) is expected to be over $500 \mathrm{bp}$. Thus, any RGAP marker with a size less than $500 \mathrm{bp}$ could be due to deletion in the intervening region while other RGAP markers with sizes over $500 \mathrm{bp}$ might correspond to functional R-genes, provided that RGAP fragments were indeed NBS-LRR R-genes. Of the 32 RGAP mapped, 19 had sizes larger than $500 \mathrm{bp}$ and 13 had sizes less than $500 \mathrm{bp}$. And size distribution of all 66 polymorphic bands were as follows: from $280 \mathrm{bp}$ to $380 \mathrm{bp} \mathrm{12,420} \mathrm{bp} \mathrm{to} 500 \mathrm{bp} 16,520 \mathrm{bp}$ to
$650 \mathrm{bp} \mathrm{23,} 700 \mathrm{bp}$ to $800 \mathrm{bp} \mathrm{6}$, and $900 \mathrm{bp}$ to 1250 bp 9.

The domain structures targeted by the primers with their degree of degeneracy are shown in Table 1 . The number of RGAP markers generated by $\mathrm{KH}$ primer sets involving conserved domains showed the extent of amino acid variation in common bean at both $\mathrm{K}$ and $\mathrm{HD}$ domains with GGVGKTT (60\%), GGIGKTT (16\%), and GLPLAL (34\%), GSPLAL (22\%), and GLPLIL $(19 \%)$, respectively. However, the codon preference at these domains appeared to be conserved. For instance, although all four K01, K02, K03, and K04 primers were designed from the GGVGKTT peptide sequence of the $\mathrm{K}$ motif, the number of RGAP markers generated from these primers (in combination with HD primers) were 7 , 1,3 , and 8 , respectively, suggesting codon usage of $\mathrm{K} 02$ and $\mathrm{K} 03$ is very low as compared to $\mathrm{K} 01$ and K04. Similarly, HD01, HD02, HD03, and HD04 are primers with varying degeneracy $(0-8)$ designed from the GLPLAL peptide sequence. The H01, HD02, HD03, and HD04 primers (in combination with $\mathrm{K}$ primers) generated $0,5,3$, and 3 RGAP markers, respectively, suggesting a strong codon preference at this domain also (Table 1).

\section{Discussion}

In this study, we mapped 32 RGAP markers on 10 of the 11 LGs of common bean. These markers are not RGA per se because the nucleotide sequences have not been determined. Even so, RGAP and RGA markers are closely related as evidenced by co-localization on six linkage groups in this study, and by association of both marker types with $\mathrm{R}$ genes/QTL and occurrence in micro-clusters. RGAP markers were associated with R-genes on B11 and QTL for resistance on B1, B2, B6, B7, B8, $\mathrm{B} 10$, and B11. For 15 classes of RGA reported by Lopez et al. (2003), nine were associated with known disease resistance genes/QTL on B4, B10, and B11. RGAPs occurred in micro-clusters on LGs B3, B5, B8, B10 and B11 which is similar to observations of Rivkin et al. (1999) for microclustering of RGAs. Specifically, generation of RGAP uses a PCR-based approach with degenerate primer combinations that targeted the conserved domains $\mathrm{K}$ (GVGKTT) and HD (GLPLAL) of the NBS-LRR class of plant 
R-genes. Thus, unlike RGA markers where RGA probes were used in cross hybridization, motif conservation was made use of directly via PCR to identify RGAP markers.

The level of polymorphism for RGAP markers was $32 \%$. Similar levels of polymorphism were previously reported with other marker systems used on this population. The combined polymorphism detected by eight restriction enzymes was $32 \%$ (Nodari 1992), and 16 of 37 SSRs generated polymorphism $(43 \%)$ between the lines BAT 93 and Jalo EEP558 (Yu et al. 2000). Thus, the level of RGAP polymorphism was identical to RFLP polymorphism and lower than SSR polymorphism. RGAPs seem to be more polymorphic than RGAs because in previous studies (Rivkin et al. 1999; Lopez et al. 2003) fewer RGAs have been generated.

Of the 32 RGAP markers, 5 (16\%) showed segregation distortion. Yu et al. (2000) reported that no SSR markers deviated from the expected 1:1 segregation ratio. However, 9\% (Nodari et al. 1993) and 18\% (Freyre et al. 1998) segregation distortion was reported for the BAT 93/Jalo EEP558 RIL population. Thus, segregation distortion observed with RGAP markers was similar to that reported for RFLP markers.

The clustering of NBS-containing sequences and QTL for resistance to pathogens suggests that the mechanisms of qualitative and quantitative resistance may be similar in some cases and indeed genes controlling quantitative resistance were proposed to share homologies with cloned R-genes (Lefebvre and Chevre 1995; Gebhardt and Valkonen 2001). Reports supporting this hypothesis are increasing. Major R-genes have been mapped in the same genomic regions as QTL, indicating the possibility of existence of common structural elements between qualitative and quantitative resistance in different crop plants (Ritter et al. 1991; Leonards-Shippers et al. 1992; Lefebvre and Palloix 1996; Caranta et al. 1997; Geffroy et al. 2000; Jeong et al. 2001). QTL for disease resistance and known R-genes reside as tightly linked clusters on chromosomes V, XI, and XII of potato (Gebhardt and Valkonen 2001), soybean LG F (Jeong et al. 2001), and common bean LGs B2, B4, B7, B8, and B11 (Geffroy et al. 2000; Kelly et al. 2003). Co-localization of RGAs with known R-genes and/or QTL for resistance to pathogens has been reported in common bean (Creusot et al.
1999; Rivkin et al. 1999; Geffroy et al. 2000; Lopez et al. 2003) and various other crop plants (Kanazin et al. 1996; Leister et al. 1996; Yu et al. 1996; Aarts et al. 1998; Seah et al. 1998; Shen et al. 1998; Speulman et al. 1998; Spielmeyer et al. 2000). Similarly, RGAP markers co-localized with many QTL for resistance to different diseases on $\mathrm{B} 2, \mathrm{~B} 6, \mathrm{~B} 8, \mathrm{~B} 10$, and $\mathrm{B} 11$ providing further support that a common mechanism exists between Rgenes and QTL for resistance in common bean as well. Rust resistance genes and an anthracnose resistance gene flanked seven RGAP markers on B11.

The co-localizations with resistance QTL and known R-genes as depicted in Figure 1 suggest that the RGAP markers are either linked to or part of the mapped R-genes/QTL. However, many of the known R-genes and resistance QTL presented in the BAT 93/Jalo EEP558 population derive from integration with other mapping populations (Kelly et al. 2003). Therefore, location of the genes in the core map represents only an approximation of genomic placement because correlation over short distances of the order of $10-15 \mathrm{cM}$ or less among the LGs of different maps is not a fixed value due to differences in genetic backgrounds and recombination events. Thus, the RGAP markers in reality might be linked either much closer to or further from the R-genes and QTL reported above. As more R-genes and resistance QTL are added to the core map, it will be interesting to see if they position near RGAP markers currently unassociated with resistance traits on LGs B3, B5, and B9.

Taking known NBS-LRR R-genes as reference points, the intervening region between $\mathrm{K}$ and $\mathrm{HD}$ priming sites is expected to be $510-520 \mathrm{bp}$. In our study, 13 of the 32 RGAP markers had sizes $500 \mathrm{bp}$ or less and 19 had sizes larger than $500 \mathrm{bp}$. In similar studies, genomic PCR fragments of RGAs contained up to two introns that gave rise to larger than expected fragments and were more polymorphic in sugar beet (Hunger et al. 2003). Thus, the 19 RGAP markers with 500 bp or larger fragment sizes could be due to the presence of introns, assuming that marker fragments were true RGA. However, Rivkin et al. (1999) reported 600 and $700 \mathrm{bp}$ DNA amplification products with similar target primers but only the $600 \mathrm{bp}$ fragment yielded NBS-LRR type sequences. Of the 66, 4 polymorphic fragments between the sizes 700 
and $750 \mathrm{bp}$ were evaluated in this study. The marker K1H3a.720 was mapped with other RGAP markers on B10.

This PCR-based mapping approach of designing degenerate primers from conserved domains may be further utilized for mapping of other gene families, provided that they have enough conservation in two or three domains within their protein sequence. It is the sequence information and better sequence analysis tools that make this approach applicable for 'gene family targeted mapping via PCR'. As shown in this study, both amino acid and codon usage differences at the priming sites can be utilized in designing degenerate primers, which would target all possible amino acid and codon differences of a given conserved domain in a gene family. Such primers would target all genes carrying any combinations of those domains known to exist in that particular gene family. Indeed, a similar approach has been used to study the peroxidase gene family in grasses (O. Gulsen, unpublished data).

In summary, 32 RGAP markers were added to the core map of common bean. These RGAP markers were associated with disease resistance traits in common bean. Location of several RGAP marker loci on LGs coincided with some of the previously reported RGAs and known R-genes and QTL for disease resistance in common bean. RGAP markers appear to be better candidates for locating genomic regions associated with disease resistance when compared to random DNA markers. The RGAP markers have another advantage over random DNA markers in that they represent potentially useful genes/loci, whereas random markers do not. PCR-based RGAP mapping also is much less expensive and faster than RGA mapping because RGAs require cloning and RFLP mapping. The RGAP markers described in this study should contribute to further targeting of the NBS-LRR resistance gene family in common bean.

\section{References}

Aarts M.G., Lintel Hekkert B., Holub E.B., Beynon J.L., Stiekema W.J. and Pereira A. 1998. Identification of R-gene homologous DNA fragments genetically linked to disease resistance loci in Arabidopsis thaliana. Mol. Plant Microb. Interact. 11: 251-258.

Anderson P.A., Lawrence G.J., Morrish B.C., Ayliffe M.A., Finnegan E.J. and Ellis J.G. 1997. Inactivation of the flax rust resistance gene $\mathrm{M}$ associated with loss of a repeated unit within the leucine-rich repeat coding region. Plant Cell 9: 641-651.

Baker B., Zambryski P., Staskawicz B. and Dinesh-Kumar S.P. 1997. Signaling in plant-microbe interactions. Science 276: 726-733.

Bent A.F. 1996. Plant disease resistance genes: Function meets structure. Plant Cell 8: 1757-1771.

Caranta C., Lefebvre V. and Palloix A. 1997. Polygenic resistance of pepper to potyviruses consist of a combination of isolate specific and broad-spectrum quantitative trait loci. Mol. Plant Microb. Interact. 872-878.

Collins N.C., Webb C.A., Seah S., Ellis J.G., Hulbert S.H. and Pryor A. 1998. The isolation and mapping of disease resistance gene analogs in maize. Mol. Plant Microb. Interact. 11: 968-978.

Creusot F., Macadre C., Ferrier Cana E., Riou C., Geffroy V., Sevignac M., Dron M. and Langin T. 1999. Cloning and molecular characterization of three members of the NBSLRR subfamily located in the vicinity of the Co-2 locus for anthracnose resistance in Phaseolus vulgaris. Genome 42: 254-264.

Deng Z., Huang S., Ling P., Chen C., Yu C., Weber C.A., Moore G.A. and Gmitter F.G.Jr. 2000. Cloning and characterization of NBS-LRR class resistance-gene candidate sequences in citrus. Theor. Appl. Genet. 101(5-6): 814-822.

Dixon M.S., Hatzixanthis K., Jones D.A., Harrison K. and Jones J.D. 1998. The tomato Cf-5 disease resistance gene and six homologs show pronounced allelic variation in leucinerich repeat copy number. Plant Cell 10: 1915-1925.

Flor H.H. 1956. The complementary genetic systems in flax and flax rust. Adv. Genet. 8: 29-54.

Freyre R., Skroch P.W., Geffroy V., Adam Blondon A.F., Shirmohamadali A., Johnson W.C., Llaca V., Nodari R.O., Pereira P.A., Tsai S.M., Tohme J., Dron M., Nienhuis J., Vallejos C.E. and Gepts P. 1998. Towards an integrated linkage map of common bean. 4. Development of a core linkage map and alignment of RFLP maps. Theor. Appl. Genet. 847-856.

Gebhardt C. and Valkonen J.P. 2001. Organization of genes controlling disease resistance in the potato genome. Annu. Rev. Phytopathol. 39: 79-102.

Geffroy V., Creusot F., Falquet J., Sévignac J., Adam-Blonden A.F., Bannerot H., Gepts P. and Dron M. 1998. A family of LRR sequences in the vicinity of the Co-2 locus for anthracnose resistance in Phaseolus vulgaris and its potential use in marker-assisted selection. Theor. Appl. Genet. 96: 494-502.

Geffroy V., Sévignac M., De Oliveira J., Fouilloux G., Skroch P., Thoquet P., Gepts P., Langin T. and Dron M. 2000. Inheritance of partial resistance against Colletotrichum lindemuthianum. Plant Microb. Interact. 13: 287-296.

Gentzbittel L., Mouzeyar S., Badaoui S., Mestries E., Vear F., de Labrouhe D. and Nicolas P. 1998. Cloning of molecular markers for disease resistance in sunflower, Helianthus annuus L. Theor. Appl. Genet. 519-525.

Hammond-Kosack K. and Jones J.D.G. 1997. Plant disease resistance genes. Annu. Rev. Plant Physiol. Plant Mol. Biol. 575-607.

Hunger S., Gaspero G. di, Mohring S., Bellin D., Schafer-Pregl R., Borchardt D.C., Durel C.E. and Werber M. 2003. Isolation and linkage analysis of expressed disease-resistance 
gene analogues of sugar beet (Beta vulgaris L.). Genome 46(1): 70-82.

Jeong S.C., Hayes A.J., Biyashev R.M. and Saghai Maroof M.A. 2001. Diversity and evolution of a non-TIR-NBS sequence family that clusters to a chromosomal "hotspot" for disease resistance genes in soybean. Theor. Appl. Genet. 103(2-3): 406-414.

Jones D.A., Thomas C.M., Hammond-Kosack K.E., BalintKurti P.J. and Jones J.D. 1994. Isolation of the tomato Cf-9 gene for resistance to Cladosporium fulvum by transposon tagging. Science 266: 789-793.

Kanazin V., Marek L.F. and Shoemaker R.C. 1996. Resistance gene analogs are conserved and clustered in soybean. Proc. Natl. Acad. Sci. USA 93: 11746-11750.

Kelly J.D., Gepts P., Miklas P.N. and Coyne D.P. 2003. Tagging and mapping of genes and QTL and molecular markerassisted selection for traits of economic importance in bean and cowpea. Field Crops Res. 82: 135-154.

Kosambi D.D. 1944. The estimation of map distances from recombination values. Annu. Eugen. 172-175.

Lander E.S., Green P., Abrahamson J., Barlow A., Daly M., Lincoln S.E. and Newburg L. 1987. MAPMAKER: an interactive computer package for constructing primary genetic linkage maps of experimental and natural populations. Genomics 174-181.

Lefebvre V. and Chevre A.-M. 1995. Tools for marking plant disease and pest resistance genes. Agronomie 3-19.

Lefebvre V. and Palloix A. 1996. Both epistatic and additive effects of QTLs are involved in polygenic induced resistance to disease: a case study, the interaction pepper-Phytophthora capsici Leonian. Theor. Appl. Genet. 503-511.

Leister D., Ballvora A., Salamini F. and Gebhardt C. 1996. A PCR-based approach for isolating pathogen resistance genes from potato with potential for wide application in plants. Nat. Genet. 14: 421-429.

Leister D., Kurth J., Laurie D.A., Yano M., Sasaki T., Devos K., Graner A. and Schulze-Lefert P. 1998. Rapid reorganization of resistance gene homologues in cereal genomes. Proc. Natl. Acad. Sci. USA 95: 370-375.

Leonards-Schippers C., Gieffers W., Salamini F. and Gebhardt C. 1992. The R1 gene conferring race-specific resistance to Phytophthora infestans in potato is located on potato chromosome V. Mol. Gen. Genet. 233: 278-283.

Lopez C.E., Acosta I.F., Jara C., Pedraza F., Gaitan-Solis E., Gallego G., Beebe S. and Tohme J. 2003. Identifying resistance gene analogs associated with resistances to different pathogens in common bean. Phytopathology 93(1): 88-95.

Martin G.B. 1999. Functional analysis of plant disease resistance genes and their downstream effectors. Curr. Opin. Plant Biol. 2: 273-279.

Meyers B.C., Chin D.B., Shen K.A., Sivaramakrishnan S., Lavelle D.O., Zhang Z. and Michelmore R.W. 1998. The major resistance gene cluster in lettuce is highly duplicated and spans several megabases. Plant Cell 10: 1817-1832.

Nodari R.O. 1992. Towards an integrated map of common bean (Phaseolus vulgaris $\mathrm{L}$.). $\mathrm{PhD}$ diss., University of California, Davis.
Nodari R.O., Tsai S.M., Guzman P., Gilbertsonand R.L.P. and Gepts P. 1993. Toward an integrated linkage map of common bean. III. Mapping genetic factors controlling host-bacteria interactions. Genetics. 134: 341-350.

Ouedraogo J.T., Gowda B.S., Jean M., Close T.J., Ehlers J.D., Hall A.E., Gillaspie A.G., Roberts P.A., Ismail A.M., Bruening G., Gepts P., Timko M.P. and Belzile F.J. 2002. An improved genetic linkage map for cowpea (Vigna unguiculata L.) combining AFLP, RFLP, RAPD and biochemical markers. Genome 45(1): 175-188.

Pflieger S., Lefebvre V., Caranta C., Blattes A., Goffinet B. and Palloix A. 1999. Disease resistance gene analogs as candidates for QTLs involved in pepper-pathogen interactions. Genome 42: 1100-1110.

Ritter E., Debener T., Barone A., Salamini F. and Gebhardt C. 1991. RFLP mapping on potato chromosomes of two genes controlling extreme resistance to potato virus X (PVX). Mol. Gen. Genet. 227: 81-85.

Rivkin M.I., Vallejos C.E. and McClean P.E. 1999. Diseaseresistance related sequences in common bean. Genome 42: 41-47.

Seah S., Sivasithamparam K., Karakousis A. and Lagudah E.S. 1998. Cloning and characterisation of a family of disease resistance gene analogs from wheat and barley. Theor. Appl. Genet. 937-945.

Shen K.A., Meyers B.C., Islam Faridi M.N., Chin D.B., Stelly D.M. and Michelmore R.W. 1998. Resistance gene candidates identified by PCR with degenerate oligonucleotide primers map to clusters of resistance genes in lettuce. Mol. Plant Mic. Int. 11(8): 815-823.

Speulman E., Bouchez D., Holub E.B. and Beynon J.L. 1998. Disease resistance gene homologs correlate with disease resistance loci of Arabidopsis thaliana. Plant J. 14: 467-474.

Spielmeyer W., Huang L., Bariana H., Laroche A., Gill B.S. and Lagudah E.S. 2000. NBS-LRR sequence family is associated with leaf and stripe rust resistance on the end of homoeologous chromosome group 1S of wheat. Theor. Appl. Genet. 1139-1144.

Staskawicz B.J., Ausubel F.M., Baker B.J., Ellis J.G. and Jones J.D. 1995. Molecular genetics of plant disease resistance. Science 268: 661-667.

Vallejos C.E., Skroch P.W. and Nienhuis J. 2001. Phaseolus vulgaris - The common bean integration of RFLP and RAPD-based linkage maps. In: Phillips R.L. and Vasil I.K. (eds), DNA-Based Markers in Plants. Kluwer Academic Publishers, Netherlands, pp. 301-317.

Yu Y.G., Buss G.R. and Maroof M.A. 1996. Isolation of a superfamily of candidate disease-resistance genes in soybean based on a conserved nucleotide-binding site. Proc. Natl. Acad. Sci. USA 93: 11751-11756.

Yu K., Park S.J. and Poysa V. 2000. Marker-assisted selection of common beans for resistance to common bacterial blight: efficacy and economics. Plant Breed. 119: 411-415. 